\title{
Mit tanulhatunk a globális OKTATÁSPOLITIKAI RENDSZEREKTŐL?
}

\author{
FAZEKAS ÁGNES
}

\author{
ELTE PPK Felnőttképzés-kutatási és Tudásmenedzsment Intézet
}

Beérkezett: 2021. november 14., elfogadva: 2021. november 19.

Christian Ydesen (ed.): The OECD's Historical Rise in Education. Cham, 2019.

Springer International Publishing. xix + 308 pp. DOI: 10.1007/978-3-030-33799-5

„Episztemikus közösség” „Szupertanker." „Statisztikai intézet." Vajon mi lehet a közös bennük? E kifejezések mindegyike egy-egy metafora arra, hogy miképpen lehet értelmezni az OECD (Organisation for Economic Co-operation and Development) globális szervezetnek az oktatásban betöltött szerepét. A fentebb idézett metaforák egy olyan beszélgetésben jelentek meg, amelyet két történész, Christian Ydesen, a dán Aalborg University és Elisa Prosperetti, az amerikai Mount Holyoke College oktatója folytatott (Prosperretti 2021). A beszélgetés apropója az a két éve, 2019-ben megjelent kötet volt (The OECD's Historical Rise in Education - The Formation of a Global Governing Complex), amely az OECD oktatási ágazatban betöltött szerepét történelmi perspektívába helyezve elemezte, és amelynek a fent említett beszélgetés egyik résztvevője, Christian Ydesen volt a szerkesztője. Ydesen és munkatársai e kötet megalkotásával a történelem egy különösen érdekes és fontos fekete dobozának tartalmát, mélyebb összefüggéseit tárják elénk. Az alábbi írás célja gyors áttekintést, ízelítőt adni abból a gazdag világból, amit e kötet az érdeklődő olvasóknak kínál.
Felmerül a kérdés, hogy vajon az OECD oktatási területen végzett tevékenységének történeti megismerése, a kapcsolódó szakpolitikai mechanizmusok mély megértése milyen területeken segítheti az olvasók gondolkodását. Vajon mennyire tekinthetjük szüknek azt a kört, amelyik valós gyakorlati tudást szerezhet a könyvben bemutatott ismeretek révén? Vajon a szakpolitikai folyamatok tervezői és elemzői mellett hol azonosíthatóak azok az oktatási szereplők, akik számára többet nyújthat ez a könyv egy izgalmas olvasmánynál?

A fenti kérdések megválaszolását nagyban segíti, ha látjuk: az implementáció és innovációmenedzsment elméleti háttere ami jelenleg szerves része az intelligens felépítésü közoktatásivezetö-képzések kurrikulumának, és egyre gyakrabban a különböző szakterületű pedagógusképzéseknek is kurrens témája - nagymértékben a nemzetközi fejlesztőszervezetek tapasztalataira épül. E globális szervezetek (lásd: development organizations, development agencies) az oktatás területén végzett több évtizedes fejlesztési tapasztalataik révén egyedülálló tudásra tettek szert. Olyan fogalmak megszületése vagy fogalmak jelentésének komoly tartalommal való feltöltése kötődik tevékenységeikhez, mint például az abszorpciós kapacitás, a tulajdonosi érzet, az átláthatóság és elszámoltathatóság, 
az ágazatközi együttmüködések, vagy az eredményeken alapuló menedzsment (lásd pl. OECD 1991, 2005; OECD-The World Bank 2006). E szervezetek tevékenységének tanulmányozása különösen értékes tudáshoz segítheti hozzá az oktatási intézmények müködése iránt akár mikro-, akár makroszintről érdeklődő elméleti és gyakorlati szakembereket. Egyedülálló lehetőséget kínál arra, hogy megértsük, mely beavatkozás mely fejlesztési kontextusban milyen feltételek mellett vezethet valóban mély és tartós hatások eléréséhez (Fazekas 2021).

Napjainkban a nemzetközi színtéren nagyszámú támogató szervezet ${ }^{1}$ múködik, amelyek méretükben és az általuk vállalt feladatokban jelentősen eltérnek egymástól. Az első fejlesztőszervezetek Európában a második világháború után jöttek létre a háború okozta károk enyhítésére. Tevékenységük eleinte az infrastrukturális fejlesztésekre koncentrálódott, de mára már jellemzően elmozdult a komplex

Halász-Szöllősi 2012-es gyűjtése alapján: Nemzetközi fejlesztöszervezetek: Világbank, Egyesült Nemzetek Szervezete, United Nations Development Programm, Európai Unió, EuropeAid, Európai Képzési Alapítvány, Organisation for Economic Co-operation and Development. Nemzeti kormányok fejlesztöszervezetei: United States Agency for International Development, UK government's Department for International Development, Australian Government Overseas Aid Program, Canadian International Development Agency, Norwegian Agency for Development Cooperation, Swedish International Development Cooperation Agency, German Agency for International Cooperation, The Federal Ministry for Economic Cooperation and Development, Germany, Japan International Cooperation Agency, Dutch Ministry of Foreign Affairs, Spanish Agency for International Development, Agence Francaise de Developpement, Danish Ministry of Foreign Affairs, Belgian Ministry of Foreign Affairs, Foreign Trade and Development Cooperation, Swiss Agency for Development and Cooperation, Finnish Ministry for Foreign Affairs, Irish Department of Foreign Affairs. gazdasági, társadalmi és kulturális transzformációk támogatása felé. Megváltozott a fejlesztési programok célrendszere, menedzsmentje, a bevont szereplők köre és feladata. Emögött elsősorban a fejlesztési tapasztalat általános növekedése, illetve az implementációs folyamatok kutatása és elemzése áll. A fejlesztőszervezetek közül az OECD különleges helyzetét magyarázza, hogy tevékenysége elsősorban a változási folyamatok elemzésére, monitorozására, kutatására, a jó gyakorlatok azonosítására, illetve szakpolitikai javaslattételekre fókuszál, ${ }^{2}$ továbbá hogy fejlesztési ügyekkel foglalkozó bizottsága (Development Assistance Committee - DAC) és fejlesztéskoordinációs igazgatósága (Development Co-operation Directorate - DCD) együttesen az egyik legjelentősebb szupranacionális fejlesztési tudásteremtő és -megosztó platformot alkotja (Bermingham - Rex Christensen - Casjen Mabn 2009; Clark-Huxley-Mountford 2010; Halász-Szöllösi 2012).

$\mathrm{Az}$ OECD megkerülhetetlen szereplője a globális oktatásügynek, oktatáspolitikának, befolyása meghaladja többek között az UNESCO vagy a Világbank hatását (Prosperretti 2021; Zapp 2020; Zhu et al. 2020). Azok, akik a nemzetközi fejlesztőszervezetekkel és ezen belül is az OECD történetével foglalkoznak, számos kérdésre választ kaphatnak. Így például feltárulhatnak elöttük azok a dinamikák, amelyek mentén lezajlott az eredetileg európai szintéren működő gazdasági együttműködésre fókuszáló szervezet (OEEC - Európai Gazdasági Együttműködési Szervezet) területi expanziója és nyitása az oktatás irányába. Gondolkodhatnak olyan alapvető kérdéseken, hogy humanisztikus vagy gazdasági problémaként értelmezhető-e inkább az oktatásügy, illetve hogy

Tevékenységére nem jellemzı̋ a fejlesztések közvetlen pénzügyi támogatása. 
kvantifikált eljárásokkal összehasonlítható-e az országok teljesítménye az oktatás terén. $\mathrm{A} z$ OECD tevékenysége emellett számos - akár az egyes iskolák menedzselésének szintjén is - jól hasznosítható eszközt tár elénk. Ilyenek például a mérési eredményekre alapozott humánerőforrástervezés változatos eszközei, illetve a jó gyakorlatok gyüjtéséhez, a standardizáláshoz, a versenyhelyzet kezeléséhez kapcsolódó eljárások (Sablberg 2011; Zhu et al. 2020; Ydesen 2019). ${ }^{3}$

A kötet - címéhez hüen - az OECD oktatási területen végzett tevékenységének mélyreható áttekintését kínálja komparatív történeti megközelítést alkalmazva. Egy olyan hiánypótló kutatási projekt eredményeire épít, amely az OECD oktatási ajánlásainak, programjainak mechanizmusait és hatását vizsgálta mind a tagországokban, mind az OECD-hez nem csatlakozó országok körében. ${ }^{4}$ A projekten dolgozó nemzetközi kutatócsoport öt kontinens kutatóit foglalta magában, a kutatás kulcsfontosságú aktorokkal készített interjúkra, illetve az OECD párizsi archívumának, valamint számos nemzeti archívum forrásainak elemzésére épült (Ydesen 2019).

E rövid áttekintés keretében nincs lehetőség ezekre részletes példákat hozni, így csupán egyet említünk: Egy, az OECD-ben alkalmazott jelzőrendszer a forgalmilámpák színei (zöld, sárga, vagy piros) szerint mutatja, hogy a résztvevők hol tartanak a különböző indikátorok szerint, így a beavatkozási javaslatok elsősorban oda irányulnak, ahol piros jelzés jelenik meg (lásd: https:// www.oecd.org/env/indicators-modellingoutlooks/outlooks.htm/ [Letöltve: 2022. 01.11.]

4 A kutatást a dán Aalborg Egyetemen valósították meg 2017-2020 között The global history of the OECD in education címmel (lásd: https:// www.en.culture.aau.dk/research/projects/ global-history-oecd-in-education/ [Letöltve: 2022. 01. 11.]
A kötet bevezetőjében a szerkesztő rövid átfogó képet ad az OECD oktatási szerepvállalásának megerősödéséröl, kiemelve a történelmi szempontból meghatározó eseményeket, értelmezi a szervezet által alkalmazott eszközöket, pozicionálja azokat a kormányzási megközelítések rendszerében, továbbá felvázolja a kötet várható tartalmát. Ezt követően három meghatározó tartalmi egységre tagolódik a kötet. Elsőként történeti megközelítésből értelmezi az OECD oktatásban betöltött szerepét és annak megerősödését, beleértve az oktatási agendák megjelenését, a kapcsolódó prioritások formálódását, a nemzetközi nagymintás mérések és a szakpolitikai jelentések szerepét. Majd esettanulmányok bemutatásával nemzeti szakpolitikai perspektívából elemzi a szervezet befolyását, itt elsősorban az egyes országok szintjén keletkező válaszokra fokuszálva. Végül a harmadik részben arra a kérdésre kaphatunk választ, hogy miként tekinthetünk az OECD-programokra globális perspektívából, milyen tendenciák, célok és eszközök rajzolódnak ki leginkább. A kötet gazdagon tartalmaz olyan képeket és idézeteket, amelyek hozzáférhetővé teszik az olvasó számára a felidézett korokat. Így például már a kötet első oldalán találkozhatunk Francois Keppel amerikai oktatási biztos ismert mondatával, miszerint „az oktatásért folytatott küzdelem túl fontos ahhoz, hogy kizárólag a pedagógusokra bízzuk" (Ydesen 2019: 1). Ez a kijelentés félreérthetetlenül jelzi, hogy az oktatás természeténél fogva nem csupán a kurrikulumról, a kompetenciafejlesztésröl szól, hanem legalább ennyire politikai kérdésekről is - különböző események, mint pl. a hidegháború vagy a Szputnyikválság ráadásul még katalizálták is ezeket a hatásokat (Prosperretti 2021).

$\mathrm{Az}$ Ydesen által szerkesztett kötet az első nagy tartalmi egységben azt a lassú 
átalakulást mutatja be, amely nyomán az 1960-as években az OECD napirendi kérdései között az oktatás különösen nagy hangsúlyt kapott, és aminek következtében 1965-ben megalakult az oktatáskutatással és oktatási innovációkkal foglalkozó szervezeti egysége, a CERI (Centre for Educational Research and Innovation). E folyamaton belül elsőként az OEEC-ben működő Európai Termelékenységi Ügynökség (European Productivity Agency) tevékenységét és befolyását elemzi (2. fejezet, Regula Bürgi), ${ }^{5}$ majd a korai amerikai hatások átfogó rendszerét, a nemzetállamok közötti politikai-gazdasági-ideológiai kapcsolatokat, feszültségeket tárja elénk (3. fejezet, Maren Elfert). Ezt követöen az OECD oktatáspolitikai színterének születésére és formálódására fókuszál, egészen a kötet megszületésének évéig (2019) vizsgálva a fogalmi, a szervezeti és a szakpolitikai átalakulásokat (4. fejezet, Vera G. Centeno). Tekintettel arra, hogy az OECD ereje mögött többek között azok a kormányzási mechanizmusok állnak, amelyek hozzákapcsolódnak adatgyüjtési és feldolgozási tevékenységekhez, az elemzések többsége erősen fókuszál a kvantifikálható adatok (ezen belül is a PISA-mérések) alkalmazásának kérdéseire (Prosperretti 2021; Ydesen 2019; Zhu et al. 2020).

A kötet második tartalmi egysége esettanulmányokkal szemlélteti, hogy az OECD oktatás területén végzett tevékenysége milyen mechanizmusokon át, milyen hatásokat tud elérni az egyes nemzetek szintjén. A felvezetőben és az első tartalmi egységben hangsúlyozza: az OECD tevékenységét puha kormányzási eszközök jellemzik, a szervezetnek nincs specifikus felhatalmazása arra, hogy beavatkozásokat tegyen az egyes országok

Zárójelben a kapcsolódó fejezet után annak szerzője látható. oktatási rendszerein belül. Szakpolitikai ajánlásokkal próbálja rásegíteni az országok oktatási területen végzett tevékenységét egy olyan vágányra, amely a globalizációs versenyben hosszabb távon elönyhöz tudja juttatni azokat (Prosperretti 2021). E tartalmi egységen belül megismerkedhetünk az OECD feltételezhető hatásával a különböző nemzeti oktatási rendszerekre, így az ausztrál (5. fejezet, Frederik Ørskov), a brazil (6. fejezet, Gabriela Silva), a dán (7. fejezet, Karen Anderson), a kínai (8. fejezet, Yihuan Zou), illetve az argentin, az uruguayi és a chilei (9. fejezet, Felicitas Acosta) oktatásra. Jól kirajzolódik, hogy a nemzeti rendszereket számos irányból érik hatások, amelyek együttesen alakítják az oktatáson belüli változásokat, és ezen hatótényezők közül az OECD csupán egy - bár igen erős - faktort jelent. Így egy olyan közös kiindulópont, mint a PISA-mérés, jelentősen eltérő szakpolitikai válaszokat, illetve változási folyamatokat indíthat el az adott nemzeti kontextusnak megfelelöen.

A kötet záró része az OECD oktatási kezdeményezéseit és programjait mutatja be globális perspektívából. E tartalmi egységben olyan irányítási eszközök, módszerek és a hozzájuk kapcsolódó dilemmák jelennek meg, amelyek tipikusan jellemzik az OECD gyakorlatát, és amelyek megkerülhetetlennek tünnek a sikeres fejlesztési folyamatok menedzselése szempontjából. E tartalmi egység elsőként a megosztott vezetés, illetve az iskolák és pedagógusok elszámoltathatóságának kérdésével foglalkozik kritikai megközelítéssel, hangsúlyozva e kettő összemosódásában rejlő veszélyeket (10. fejezet, Jessica Holloway). Ezt követően az elszámoltathatóságot mint az iskolai autonómia erősítési lehetőségét tárgyalja (School autonomy with accountability - SAWA), olyan kapcsolódó eljárásokat mutatva be, mint az adatgyüjtés, a szakpolitikai értékelés és 
az ötlet-, illetve tanácsadás (11. fejezet, Antoni Verger és mtsai). Majd reflektál az európai térségben lezajló folyamatokra is, bemutatja, miként fejlődött az európai oktatáspolitika transznacionális együttműködéseken keresztül (12. fejezet, John Krejsler). A tartalmi egységet a kötet szerkesztőjének tanulmánya zárja, amely szintetizálja a korábbi fejezeteket, beleértve a kötet első két szerkezeti egységét is. Itt egy olyan áttekintést kapunk, amely átfogó jellege mellett érzékletes történelmi példákkal támasztja alá a megállapításokat.

Bár a kötet már rögtön az első fejezetben úgy értelmezi az OECD történetét, mint metaszintre emelkedő tudások forrását, a kirajzolódó összefüggések megfogalmazása megmarad a szupranacionális, illetve nemzeti folyamatok szintjén. Azok, akik az itt megjelenő fejlesztési tudások és eszközök intézményi, illetve iskolai szintű adaptálásának lehetőségét keresik, szükséges, hogy éles szemmel, különös érzékenységgel ismerkedjenek meg e kötettel, illetve, hogy olykor a szöveget elhagyva, egyéb forrásokból fedezzék fel az egyes fejlesztési megfontolások vagy eszközök konkrét alkalmazásának gyakorlatát. Így például fontos kiegészítést adhat az a kötet recenzióját felvállaló tanulmány (Zbu et al. 2020), amely összegezte a kötetből tisztán kirajzolódó, de ott direkt módon kevéssé megjelenő fejlesztési irányelveket (lásd pl. adatokon, versenyhelyzeten, a jó gyakorlatokon alapuló irányítás).
$\mathrm{Az}$ OECD's Historical Rise in Education c. kötet igazi intellektuális utazást kínál egy történeti, földrajzi, szakpolitikai és fejlesztési szempontból is gazdag világba. $\mathrm{A} z$ OECD globális szervezetének oktatási perspektívából történő bemutatása olyan hiánypótló forrás, amely számos alapvető szakmai dilemmát foglal egy történeti síkon értelmezhető, átfogó rendszerbe. Megközelítését illetően diverznek tekinthető: egyfelől határozottan jelen van a nemzetközi fejlesztőszervezetek nemzetállamokra gyakorolt hatásának pozitív mérlegébe vetett hit, másfelől alkalmaz kritikai megközelítéseket is. Jól illusztrálja azokat a kétértelmüségeket, illetve ellentmondásokat, amelyek egy formálódó identitással, számos irodával, részleggel, projektelv szerint változó szakterületű és értékrendszerü munkatárssal működő szervezet esetében megkerülhetetlennek látszanak. Emellett hangsúlyosan foglalkozik olyan alapvető dilemmákkal, mint amilyen az oktatás humanisztikus vagy gazdasági megközelítésének relevanciája, a komplex rendszerek értelmezhetősége és összehasonlíthatósága, a nemzetközi szinten homogén, egypólusú oktatásügy létjogosultsága vagy a globális mérési rendszerek alkalmazhatósága. Azok számára, akik többet szeretnének megtudni az OECD történetét feltáró kutatás eredményeiről, a kutatás honlapján elérhetőek a kötet megjelenése után született további publikációk és egyéb disszeminációs források is. ${ }^{6}$

Lásd: https://www.en.culture.aau.dk/research/ projects/global-history-oecd-in-education 


\section{IRODALOM}

Bermingham, D., Rex Christensen, O. \& Casjen Mahn, T. (2009) Aid Effectiveness in Education: Why It Matters? Prospects, Paris Vol. 39, Iss. 2, 39. pp. 129-145.

Clark, G., Huxley, J. \& Mountford, D. (2010) Organising Local Economic Development. The Role of the Development Agencies and Companies. Paris, OECD.

FAzeKas Á. (2021) Közoktatás-fejlesztési beavatkozások hatásmechanizmusai. Budapest, Akadémiai Kiadó.

Halász G. \& Szőllősı T. (2012) A fejlesztő beavatkozások hatásmechanizmusainak kérdései a nemzetközi fejlesztőszervezetek tevékenységében. Budapest, ELTE PPK Felsőoktatás-menedzsment Intézeti Központ. (Kézirat.)

OECD (1991) DAC Principles for Evaluation of Development Assistance Development Assistance Committee. Paris, OECD Publishing.

OECD (2005) The Paris Declaration on Aid Effectiveness. Paris, OECD Publishing.

OECD-The World Bank (2006) Emerging Good Practice in Managing for Development Results. First issue.

Prosperetti, E. (2021) The OECD's Historical Rise in Education: The Formation of a Global Governing Complex. An interview with Christian Ydesen. https://newbooksnetwork. com/the-oecds-historical-rise-in-education [Letöltve: 2021. 11. 19.]

Sahlberg, P. (2011) The Fourth Way of Finland. Journal of Educational Change, Vol. 12. No. 2. pp. 173-85.

ZApp, M. (2020) The Authority of Science and the Legitimacy of International Organisations: OECD, UNESCO and World Bank in Global Education Governance. Compare. DOI: 10.1080/03057925.2019.1702503

Zhu, G., Xu, G., Li, Y. \& Chen, B. (2020) Typology of OECD’s Global Educational Governance and Its Policy Effect. Comparative Education Review, Vol. 64. pp. 525-542. DOI: $10.1086 / 709665$

A cikk a Creative Commons Attribution 4.0 International License (https://creativecommons.org/licenses/ by-nc/4.0/) feltételei szerint publikált Open Access közlemény, melynek szellemében a cikk bármilyen médiumban szabadon felhasználható, megosztható és újraközölhető, feltéve, hogy az eredeti szerző és a közlés helye, illetve a CC License linkje és az esetlegesen végrehajtott módosítások feltüntetésre kerülnek. 